\title{
KEGIATAN PELAKSANAAN PEMELIHARAAN TANAM POHON KAMPUNG BUNGA WARNA WARNI DI DESA SUKALAKSANA RW.01 RT.016
}

\author{
Lina Marlina \\ Universitas Banten Jaya, Jl Syech Nawawi Albantani Serang, Banten, Indonesia \\ Email: linamarlina@unbaja.ac.id
}

\begin{abstract}
Community service activities in the implementation of the maintenance of planting colorful flower village trees in Sukalaksana Village RW.01 RT.016 as a form of environmental conservation that needs to be cultivated, this activity is carried out with the involvement of the Sukalaksana Village community, Youth Organizations, and a team of KKM Students Group 11 UNBAJA 2021. The Maintenance of Planting Colorful Flower Village Trees in Sukalaksana Village RW.01 RT.016 is expected to be able to make the first tap of public awareness to have concern for the environment, especially in this flower village or also called by its original name Kaningan village. This activity not only aims to realize reforestation in Sukalaksana village, but it is also one of the work programs of the 2021 Unbaja Group 11 KKM team, In this community service program method, the team uses an activity method with several stages, namely the Planting Planning stage, Planting Preparation, Determination of Candidate Locations, Need for Number of Seeds, Planting Design, namely the preparation and selection of plant types. Next is tree planting, namely the stage of the tree planting process, from this community service the results obtained are increasing public awareness to have a concern for the environment and nature conservation, especially in this flower village in Sukalaksana Village.
\end{abstract}

Keywords: Maintenance; Planting Trees; Colorful Flower Village; Sukalaksana Village.

\begin{abstract}
ABSTRAK
Kegiatan pengabdian masayarakat pada pelaksanaan pemeliharaan tanam pohon kampung bunga warna warni di Desa Sukalaksana RW.01 RT.016 sebagai bentuk pelestarian lingkungan yang perlu dibudidayakan, kegiatan ini dilaksanakan dengan adanya pelibatan masyarakat Desa Sukalaksana, Karang Taruna, dan Tim dari Mahasiswa KKM Kelompok 11 UNBAJA 2021. Kegiatan Pelaksanaan Pemeliharaan Tanam Pohon Kampung Bunga Warna Warni Di Desa Sukalaksana RW.01 RT.016 pohon ini diharapkan mampu menjadikan keran pertama kesadaran masyarakat untuk memiliki kepedulian terhadap lingkungan khususnya pada kampung bunga ini atau disebut juga dengan nama aslinya kampung kaningan. Kegiatan ini tidak hanya bertujuan untuk mewujudkan Penghijauan di desa Sukalaksana $\mathrm{h}$ al tersebut juga menjadi salah satu program kerja dari tim KKM Kelompok 11 Unbaja 2021, pada metode program pengabdian kepada masyarakat ini tim menggunakan metode kegiatan dengan beberapa tahapan yakni tahap Perencanaan Penananaman, Persiapan Penanaman, Penetapan Calon Lokasi, Kebutuhan Jumlah Bibit, Rancangan Penanaman yaitu kegiatan persiapan dan pemilihan jenis tanaman Selanjutnya adalah penanaman pohon yaitu tahap dilakukannya proses penanaman pohon, dari pengabdian masyarakat ini hasil yang didapatkan adalah peningkatan kesadaran masyarakat untuk memiliki kepedulian terhadap lingkungan dan pelesatrian alam khususnya pada kampung bunga ini di Desa Sukalaksana.
\end{abstract}

Kata Kunci: Pemeliharaan; Tanam Pohon; Kampung Bunga Warna Warni; Desa Sukalaksana.

\section{PENDAHULUAN}

Indonesia sebagai negara agraris memiliki kekayaan alam yang melimpah karena didukung dengan posisinya yang strategis. Mulai dari sisi geografis, negara Indonesia 
terletak di daerah tropis yang memiliki curah hujan yang cukup tinggi sehingga banyak jenis tumbuhan yang dapat hidup dengan baik (Natha, 2020).

Indonesia dikenal memiliki hutan tropis dengan luas mencakup $1.3 \%$ dari luas permukaan bumi, tetapi memiliki tingkat keanekaragaman jenis yang tinggi, $11 \%$ jenis tumbuhan berbunga, $10 \%$ jenis mamalia, $16 \%$ jenis burung, $26 \%$ reptilia dan amfibia serta $25 \%$ jenis ikan laut dan air tawar (Supriatna, 2008) sehingga dikenal sebagai salah satu negara mega-diversity di dunia.(Hiola \& Abdullah, 2012).

Pohon merupakan salah satu atribut utama kota, sebagai penyeimbang ruang kota yang masif dengan bangunan beton dan aspal. Pohon selain berfungsi sebagai tempat istirahat dan rekreasi masyarakat kota, juga memiliki manfaat ekologi yaitu sebagai suplay oksigen, perbaikan kesuburan tanah, dan habitat satwa dengan berbagai macam burung dan serangga, juga berguna untuk meningkatkan kualitas estetika alamiah kota. Akan tetapi banyak pohon yang tergerus oleh vandalisme, hanya dijadikan tempat tempelan iklan, tergerus oleh pencemaran dari asap kendaraan, dan gangguan lainnya yang sangat mengenaskan.(Khadiyanto, 2018)

Pengabdian masyarakat ini kegiatan yang dilakukan adalah Kegiatan Pelaksanaan Pemeliharaan Tanam Pohon Kampung Bunga Warna Warni Di Desa Sukalaksana RW.01 RT.016, lokasi yang menjadi kegiatan pengabdian ini disebut juga kamoung bunga dengan alasan bahwa kampung tersebut bertujuan untuk menjadikan lingkungan sekitar kampung menjadi seperti taman bunga sehingga disebut juga sebagai kampung bunga dan nama Sali dari kampung tersebut tidak lainadalah kampung kaningan yang berlokasi di desa sukalaksana, kegiatan ini dilatar belakagi dengan adanya program Kuliah Kerja Mahasiswa (KKM) yang dilaksanakan secara rutin pada Universitas Banten Jaya yang bekerja sama dengan Kotaku.

Tema yang diangkat pada pengabdian masyarakat ini adalah Kegiatan Pelaksanaan Pemeliharaan Tanam Pohon Kampung Bunga Warna Warni Di Desa Sukalaksana RW.01 RT.016, dengan terjun langsung kelapangan agar mendapatkan data yang real dan sesuai yang ada di lapangan di tempat pengabdian. Kampung diidentikkan dengan suasana yang kurang terawat dan kumuh, oleh karena itu peneliti pengabdian berusaha untuk membersihkan kampung dengan mengecat warna warni dan penanaman pohon dan bunga agar tempat tinggal warga kampung tersebut dapat memberikan rasa nyaman serta menjadi lebih indah, bagus, dan terawat.(Surya, 2020).

Kegiatan tanam pohon dilakukan bertujuan agar lingkungan sekitar kampung desa Di Desa Sukalaksana RW.01 RT.016 khususnya menjadi lebih terlihat hijau dengan adanya proses tanam pohon agar lingkungan sekitar menjadi lebih ramah lingkungan dengan adanya 
penghijauan lingkungan seperti tanam pohon di kampung bunga atau kampung kaningan. Kegiatan ini juga menjadikan ajang sosialisasi kepada masyarakat agar selalu menjaga kebersihan serta kelestarian lisngkungan dengan melakukan kegiatan ini masyarakat setempat menjadi leih peduli kepada lingkungan sekitar khsususnya di Di Desa Sukalaksana Kampung bunga atau kampung kaningan di RW.01 RT.016. Dengan adanya Kegiatan Pelaksanaan Pemeliharaan Tanam Pohon Kampung Bunga Warna Warni Di Desa Sukalaksana RW.01 RT.016, tidak hanya memberikan rasa peduli lingkungan kepada masayarakat sekitar akan tetapi juga menjadikan salah satu kampung Di Desa Sukalaksana RW.01 RT.016 menjadi kampung indah dengan banyak aneka ragam bunga warna warrni yang ditanam oleh warga dan tim pengabdian yang menjadi salah satu program kerja tim kelompok 11 KKM UNBAJA 2021 yang bekerja sama juga dengan pihak Kotaku.

Program kerja dari Kotaku yakni Program peningkatan akses terhadap infrastruktur dan pelayanan dasar di kawasan kumuh perkotaan untuk mendukung terwujudnya permukiman perkotaan yang layak huni, produktif dan berkelanjutan dengan tujuan Menurunnya luas permukiman kumuh;Mewujudkan kolaborasi penanganan Kawasan kumuh dari berbagai stakeholder;Menyediakan infrastruktur permukiman; dengan sasaran Meningkatnya akses masyarakat terhadap infrastruktur dan pelayanan perkotaan pada permukiman kumuh sesuai dengan kriteria permukiman kumuh yang ditetapkan (a.l drainase; air bersih/minum; pengelolaan persampahan; pengelolaan air limbah; pengamanan kebakaran; Ruang Terbuka Publik);Menurunnya luasan permukiman kumuh karena akses infrastruktur dan pelayanan perkotaan yang lebih baik;Penerima manfaat puas dengan kualitas infrastruktur dan pelayanan perkotaan di permukiman kumuh.(Gambaran Program Kotaku_revisi, n.d.)

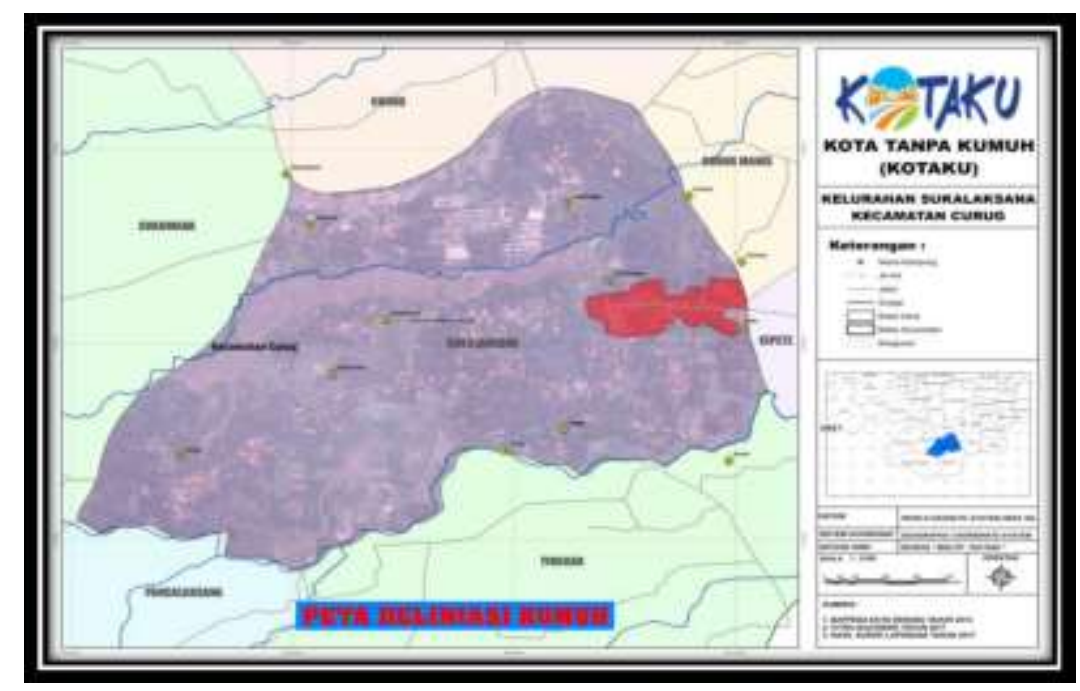

Gambar 1. Peta Gambaran Umum Kelurahan Sukalaksana 
Kelurahan Sukalaksana merupakan salah satu Kelurahan yang terletak di wilayah Kecamatan Curug dimana wilayah tersebut terletak sebelah Timur Kota Serang Kelurahan Sukalaksana terdiri dari 4 RW dan 18 RT dengan luas wilayah $\mathbf{5 0 8} \mathbf{~ h}$ jumlah penduduk 4.740 jiwa (Profil Kelurahan Sukalaksana)(Profil Kelurahan Sukalaksana 2021 (1), n.d.)

\section{METODE}

Pelaksanaan kegiatan pengabdian kepada masyarakat ini berlokasi di Kampung Kaningan RT/RW 16/01 Kelurahan Sukalaksana, Kecamatan Curug, Kota Serang. Waktu pelaksanaan kegiatan ini pada tanggal 15 Agustus 2021 selama kurang lebih 7 jam. Jumlah peserta yang mengikuti kegiatan ini kurang lebih 20 orang yang terdiri dari tokoh masyarakat desa, karang taruna, dan mahasiswa peserta KKM 2021 Universitas Banten Jaya. (Mukson, Ubaedillah, \& Wahid, 2021).

Metode yang di gunakan pada kegiatan pengabdian ini adalah metode dalam bentuk praktik dengan tahapan Kegiatan penanaman meliputi perencanaan penananaman, persiapan penanaman, penetapan calon lokasi, kebutuhan jumlah bibit, rancangan penanaman dan tahap persiapan yaitu kegiatan persiapan dan pemilihan jenis tanaman Selanjutnya adalah penanaman pohon yaitu tahap dilakukannya proses penanaman pohon.(Utama, I Made, 2020).

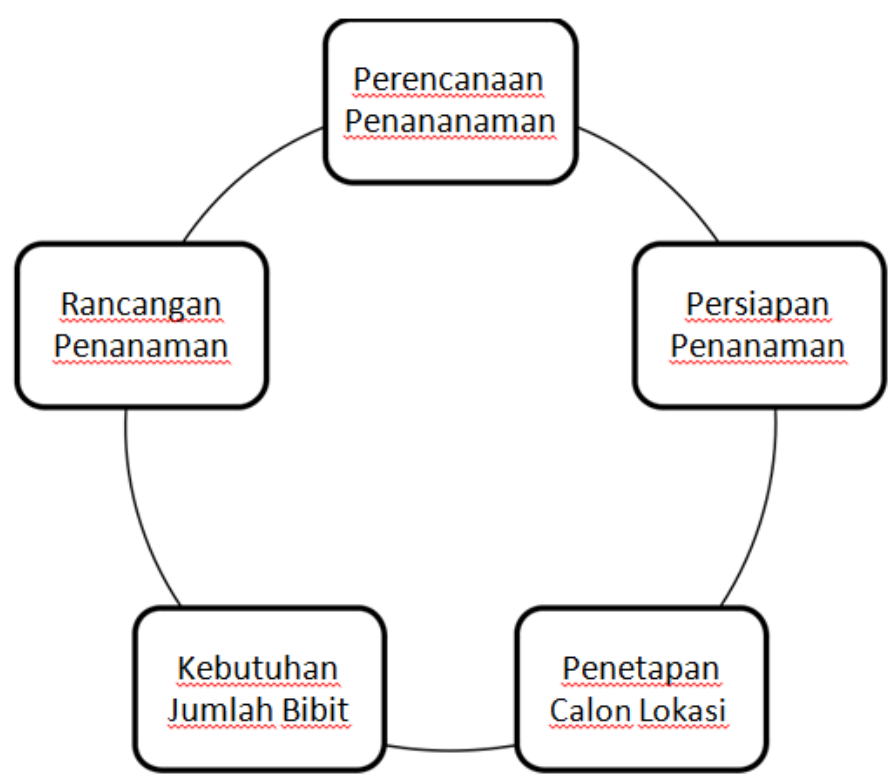

Gambar 2. Alur Kegiatan Pemeliharaan Tanam Pohon Kampung Bunga Warna Warni 


\section{HASIL DAN PEMBAHASAN}

Pada seluruh rangkaian pelaksanaan kegiatan pengabdian kepada masyarakat ini diketahui bahwa peserta sangat berpartisipasi dalam pelaksanaan kegiatan penanaman pohon. Wawancara menjadi dasar dalam pengambilan keputusan hasil pengabdian masyarakat ini (Mukson et al., 2021).

Kegiatan tanam pohon dilakukan bertujuan agar lingkungan sekitar kampung desa Di Desa Sukalaksana RW.01 RT.016 khususnya menjadi lebih terlihat hijau dengan adanya proses tanam pohon agar lingkungan sekitar menjadi lebih ramah lingkungan dengan adanya penghijauan lingkungan seperti tanam pohon di Kampung Bunga Atau Kampung Kaningan.

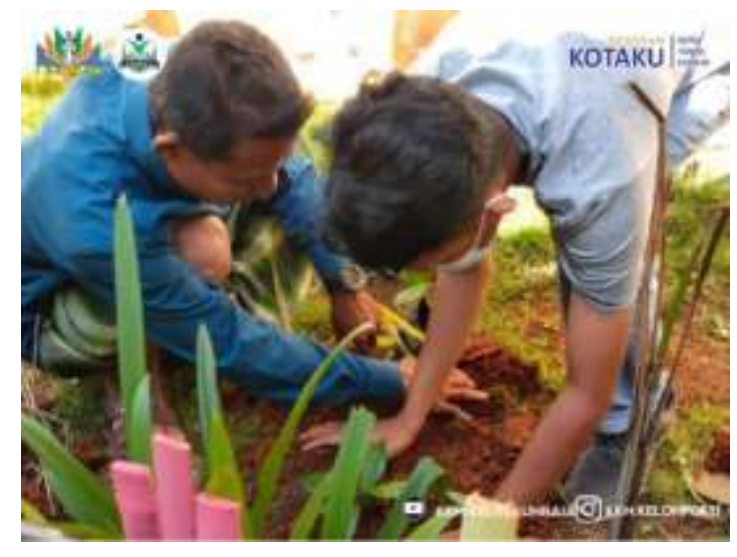

\section{Gambar 3. Kegiatan Tanam Pohon Kampung Kaningan}

Menanam pohon juga merupakan agenda nasional yang dicanangkan oleh pemerintah pusat, yaitu dengan mengajak masyarakat Indonesia untuk menanam minimal 25 pohon per warga untuk seumur hidup. Presiden menjadikan penanaman bibit pohon sebagai acara wajib saat menerima kunjungan kenegaraan para pemimpin dunia yang datang ke Indonesia. Banyak manfaat yang dapat diambil dari "ritual" menanam pohon oleh tamu kenegaraan ini. Selain melestarikan lingkungan, momen ini juga bisa dipakai untuk memperkenalkan tanaman endemic Indonesia. Kegiatan menanam pohon pada acara kenegaraan juga sekaligus kampanyegerakan penyelamatan lingkungan agar lebih mendunia (Kementerian LHK, 2017).(Asrin, Setiawan, Hamdian Affandi, Bagus Kade Gunayasa, \& Darmawan, 2019). 


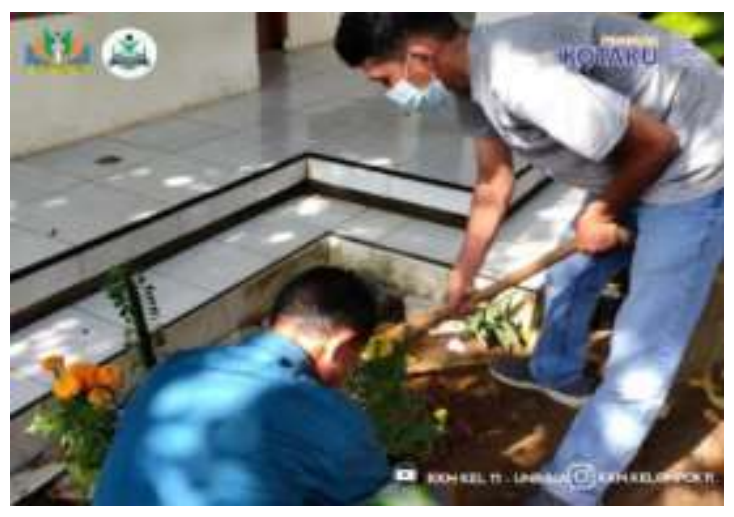

\section{Gambar 4. Proses Kegiatan Tanam Pohon di RT setempat}

Kegiatan tanam pohon dilakukan dilingkungan sekitar kampung desa Di Desa Sukalaksana RW.01 RT.016, tim pengabdi dan pihak dari tokoh masyarakat desa, karang taruna, dan mahasiswa peserta KKM 2021 Universitas Banten Jaya, memepersiapkan kegiatan ini dengan mempersipakan beberapa keperluan dan persiapan diantaranya adalah:

1. Perencanaan Penananaman

Pada kegiatan perencanaan penanaman dari pihak tim dan pihak masyarakat mengadakan diskusi terkait program tanam pohon yang akan dilakukan dengan mendiskusikan proses pelaksanaan kegiatan tersebut dari mulai persiapan awal atau tahap awal sampai dengan tahap proses tanam pohon yang akan dilakukan di Desa Sukalaksana RW.01 RT.016, dan salah satu isi dari hasil diskusi yang di simpulkan adalah tim dan pihak masyarakat membuat agenda menanam pohon sebagai simbol cita-cita menciptakan lingkungan di Desa Sukalaksana RW.01 RT.016 Kampung bunga atau Kaningan yang asri

\section{Persiapan Penanaman}

Tahapan selanjutnya adalah persiapan penanaman pada tahap ini tim dan juga pihak dari masyarakat, menetukan tanaman jenis apa saja yang akan di tanam yang sesuai dengan lahan yang ada di lokasi dan jenis tanaman yang direncanakan adalah jenis tanaman bibit pohon kecil dan bunga hiasan seperti dengan tema kampung itu sendiri yaitu kampung bunga agar kampung tersebut terlihat asri bersih dan indah dengan adanya penanaman pohon dan bunga warna warni,yang dilakukan oleh tim pengadian dan para pihak masyarakat setempat yang kemudian secara simbolis di berikan kepda pihak RT setempat sebagai perwakilan dilaksankan kegiatan tanam pohon. 


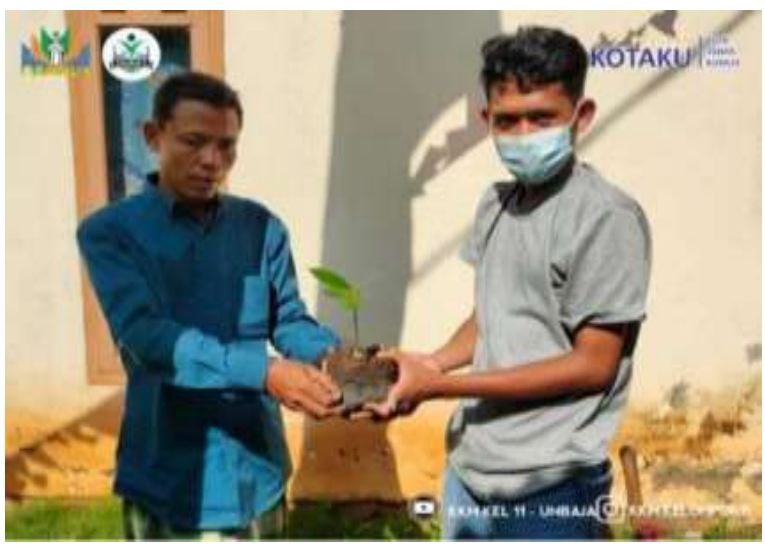

\section{Gambar 5. Agenda Tanam Pohon diserahkan secara simbolis kepada ketua RT}

\section{Penetapan Calon Lokasi}

Penetapan lokasi yang telah ditentukan oleh pihak tim pengadian dan dari pihak masyarakat maka lokasi yang akan dijadikan lokasi tanam pohon dilakukan di lokasi sekitar lingkungan Kampung Kaningan RT/RW 16/01 Kelurahan Sukalaksana, Kecamatan Curug, Kota Serang,

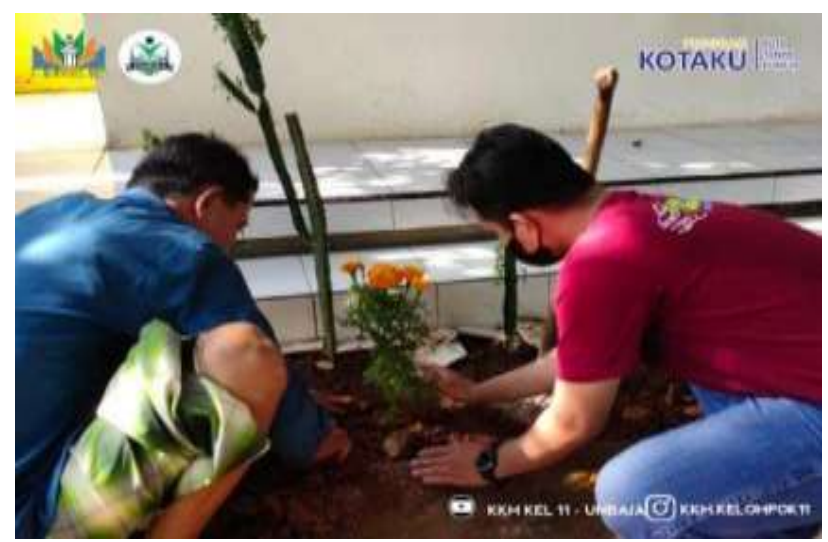

\section{Gambar 6. Proses Kegiatan Tanam Pohon oleh masyarakat dan peserta KKM}

\section{Kebutuhan Jumlah Bibit}

Dari kebutuhan jumlah bibit tim memutuskan untuk menyediakan jumlah bibit pohon, bibit pohon kecil dan bunga-bunga hias yang akan di tanam dilingkungan sekitar kampung yang berlokasi di Kampung Kaningan RT/RW 16/01 Kelurahan Sukalaksana, Kecamatan Curug, Kota Serang.

5. Rancangan Penanaman

Pada rancangan penanaman tanam pohon yang menjadi salah satu program kerja kegiatan kuliah kerja mahasiswa (KKM) 2021 pada Universitas Banten Jaya, adanya satu rancangan 
penanaman pohon berkala yang akan dipantau oleh pihak tim pengabdian dan pihak masyarakat, agar rancangan penanaman dengan adanya kegiatan tanam pohon ini dapat berkesinambungan, sehingga tema kampung bunga pada Kampung Kaningan RT/RW 16/01 Kelurahan Sukalaksana, Kecamatan Curug, Kota Serang, tetap terjaga dan menjadi ciri khas dari kampung tersebut. Evaluasi dilakukan untuk mencapai tujuan yang diinginkan dan berkelanjutan. Karena kegiatan ini merupakan salah satu kegiatan penghijauan, maka diperlukan suatu monitoring untuk menjaga agara tanaman tersebut dapat tumbuh dengan baik. Bibit yang telah ditanam, sebaiknya diperiksa terus menerus dan dilakukan penyiraman serta pemupukan agar menjaga tanaman untuk bisa tumbuh dengan baik. Apabila ditemukan salah satu tanaman jelek atau yang mati, maka secepatnya dilakukan pergantian tanaman/penyulaman agar pertumbuhan bibit yang baru tidak jauh tertinggal dengan tanaman yang lain yang telah tumbuh.(Utama, I Made, 2020).

\section{KESIMPULAN}

Berdasarkan kegiatan pengabdian kepada masyarakat yang telah dilakukan, maka dapat disimpulkan bahwa pada pengabdian masyarakat ini hasil yang didapatkan adalah untuk dapat meningkatkan kesadaran masyarakat untuk memiliki kepedulian terhadap lingkungan dan pelesatrian alam khususnya pada kampung bunga ini di Desa Sukalaksana dan dengan adanaya Kegiatan tanam pohon dilakukan bertujuan agar lingkungan sekitar kampung desa Di Desa Sukalaksana RW.01 RT.016 khususnya menjadi lebih terlihat hijau dengan adanya proses tanam pohon agar lingkungan sekitar menjadi lebih ramah lingkungan dengan adanya penghijauan lingkungan seperti tanam pohon di kampung bunga atau kampung kaningan.

Dengan adanya kegiatan tanam pohon ini masyarakat dapat lebih peduli lingkungan dan tetap menjaga kelesatrian lingkungan sekitar sehingga menjadi pribadi yang lebih dapat menjaga sekitar serta dapat menjadikan ajang sosialisasi kepada masyarakat agar selalu menjaga kebersihan serta kelestarian lingkungan dengan melakukan kegiatan ini masyarakat setempat menjadi leih peduli kepada lingkungan sekitar khsususnya di Di Desa Sukalaksana Kampung bunga atau kampung kaningan di RW.01 RT.016.

\section{UCAPAN TERIMA KASIH}

Penulis ucapkan terima kasih kepada Kepada Ketua LP3M dan para unit struktur LP3M Universitas Banten Jaya, Kepada pihak Panitia Kuliah Kerja Mahasiswa (KKM), Kepada Pihak Desa Sukalaksana Kampung Kaningan RT/RW 16/01 Kelurahan Sukalaksana, Kecamatan Curug, Kota Serang, Kepada Seluruh Peserta kegiatan Kuliah Kerja Mahasiswa (KKM) 
Universitas Banten Jaya 2021 Khususnya Kelompok 11 yang telah melasanakan kegiatan dengan sangat baik dan berupaya dengan baik untuk membantu kegiatan masyarakat khususnya di Desa Sukalaksana Kampung Kaningan RT/RW 16/01 Kelurahan Sukalaksana, Kecamatan Curug, Kota Serang yang membantu sehingga pelaksanaan kegiatan Kuliah Kerja Mahasiswa (KKM) Universitas Banten Jaya 2021 dapan berjan lancar sebagai bentuk pengabdian dan pemenuhan tri darma perguruan tinggi. yang telah membina sehingga kegiatan Kuliah Kerja Mahasiswa (KKM) bisa terlaksana dengan baik.

\section{DAFTAR PUSTAKA}

Asrin, B., Setiawan, H., Hamdian Affandi, L., Bagus Kade Gunayasa, I., \& Darmawan, M. K. (2019). Pgsd Untuk Negeri: Reboisasi, Dukung Pengembangan Kampung Hijau Berbagi Tanpa Saling Menggurui. 2(2), 2614-7947.

Gambaran Program Kotaku_revisi. (n.d.).

Hiola, A. S., \& Abdullah, S. (2012). Agroforestri ilengi: Suatu Kajian Pelestarian dan Pemanfaatan Jenis Pohon. Jurnal Ilmiah Prospek, XIV(4), 38-48. Retrieved from www.jurnalbung.com

Khadiyanto, P. (2018). PELESTARIAN POHON DI SEMARANG KOTA. TEMU ILMIAH IPLBI, 1-9.

Mukson, M., Ubaedillah, U., \& Wahid, F. S. (2021). Penanaman Pohon Sebagai Upaya Meningkatkan Kesadaran Masyarakat Tentang Penghijauan Lingkungan. JAMU: Jurnal $\begin{array}{lllll}\text { Abdi } & \text {.., } & 1(02), & 52-57 . & \text { Retrieved }\end{array}$ http://jurnal.umus.ac.id/index.php/jamu/article/view/350

Natha, I. (2020). Perancangan Komunikasi Visual Kampanye Pelestarian Pohon Aren Di Bali. Retrieved from http://digilib.isi.ac.id/id/eprint/7106

Profil Kelurahan Sukalaksana 2021 (1). (n.d.).

Surya, H. N. P. D. P. (2020). Kampung Warna Warni Berperilaku Hidup Sehat. Jurnal Leverage, Engagement, Empowerment of Community, 2(1), 1-16.

Utama, I Made, P. dkk. (2020). Praktik Pelestarian Lingkungan Melalui Kegiatan Penanaman Pohon di Kawasan Pesisir Pantai Mapak Mataram. Jurnal Pengabdian UNDIKMA: Jurnal Hasil Pengabdian \& Pemberdayaan Kepada Masyarakat Http://Ojs.Ikipmataram.Ac.Id/Index.Php/Jpu, 1(1), 65-69. 